\title{
Mobile Applications in Central Government of Brazil and Portugal
}

\author{
Débora Dutra \\ State University of Rio Grande do Sul; University of Minho \\ Campus de Azurém, \\ 4800-058, Guimarães, Portugal \\ deboradutra@gmail.com
}

\author{
Delfina Soares \\ United Nations University (UNU-EGOV) \\ Campus de Couros, Rua de Vila Flor 166 \\ 4810-445, Guimarães, Portugal \\ soares@unu.edu
}

\begin{abstract}
This research aims to explore how central governments of Brazil and Portugal are using mobile applications to offer services to citizens. To this end, 12 APPs were analysed in Brazil (which provide 25 services) and 20 APPs in Portugal (which provide 22 services) based on the following set of criteria: Service coverage; Service category; Service area; Number of services provided by the APP, Number of installations, Availability in APP stores, Access key. The main results show that in Brazil the area of government with the greatest number of services provided through APPs is Social Security; that $60 \%$ of services can be carried out entirely via APP; that almost $90 \%$ of the services offered through APPs are in the interactive stage and that the same APP offers several services. In Portugal, three areas of government stand out in the provision of mobile services: Social Support and Health; Recreation; Citizenship and Documentation, which together account for $77 \%$ of APPs offered. The vast majority of services offered by APPs are in the interactive stage (50\%) or the informational and educational stage (36\%), and typically most of the APPs in Portugal provide just one service.
\end{abstract}

\section{CCS CONCEPTS}

- Applied computing $\rightarrow$ Computers in other domains $\rightarrow$ Computing in government $\rightarrow$ E-government

\section{KEYWORDS}

m-Government. Mobile public services. e-Government

\section{ACM Reference format:}

D. Dutra, D. Soares. 2019. Mobile Applications in Central Government of Brazil and Portugal. In Proceedings of the $12^{\text {th }}$ International Conference on Theory and Practice of Electronic Governance (ICEGOV2019), Melbourne, VIC, Australia, April 3-5, 2019, 7 pages. https://doi.org/10.1145/3326365.3326377

\section{INTRODUCTION}

Extraordinary advancements in technologies have happen over the last two decades. Technological innovation has been happening at a rapid pace and reaching admirable levels of sophistication. This is particularly true with regard to mobile technologies and communications, where achievements in the provision of mobile broadband or the availability of smarter mobile devices such as tablets and smartphones are undeniable. Smartphones currently have numerous features that allow for various forms of continuous (24 hours connection a day) communication and internet access. They also allow users to have real time access to applications according to their concrete and specific needs and based on their physical location, appropriately translating the concept of customizable device.

Keeping up with this pace of transformation and with the current trend of "living on movement" became something mandatory for institutions, at a private and public level. As a consequence of this, efforts on developing mobile government solutions stood out in many countries.

Mobile government provides a channel that can extend the way public services are offered to citizens [1-2], allowing them to be provided on demand, anytime, anywhere [6]. For [3], $\mathrm{m}$-Government is a complex business strategy for the efficient use of all wireless devices, providing immediate availability of services and information for the best benefits to citizens. Mgovernment is also seen as an instrument of transformation - to expand access to existing services, to expand the provision of new

Permission to make digital or hard copies of all or part of this work for personal or classroom use is granted without fee provided that copies are not made or distributed for profit or commercial advantage and that copies bear this notice and the full citation on the first page. Copyrights for components of this work owned by others than ACM must be honored. Abstracting with credit is permitted. To copy otherwise, or republish, to post on servers or to redistribute to lists, requires prior specific permission and/or a fee. Request permissions from Permissions@acm.org.

ICEGOV2019, April 3-5, 2019, Melbourne, VIC, Australia

(C) 2019 Association for Computing Machinery.

ACM ISBN 978-1-4503-6644-1/19/04 \$15.00

https://doi.org/10.1145/3326365.3326377 
services, to increase the active participation of citizens in government operations, and to change the way they work within the public sector [4]. In this sense, [5] stresses that the change of platform made possible by mobile devices can help to improve public health, education and productivity.

In face of all the announced m-government expected benefits, how are governments making use of mobile applications (APPs) to support their interaction with citizens? Are governments really adopting m-government? Which kind of services are offered through mobile applications?

This paper tries to reply to these questions by providing results based on the analysis of 32 APPs made available by central government agencies in two concrete countries: Brazil (12 APPs) and Portugal (20 APPs).

The focus in these two countries for conducting the study stems from factors that sometimes distinguish and sometimes approximate them. As for the geographic region where the countries are, their dimensions and their economies and, more specifically, the development stage of e-Gov, from international indices, these countries differ. As far as $\mathrm{m}$-Government is concerned, it is a viable and effective alternative to the two countries - they are closer since on the one hand, Brazil has a continental extension, on the other Portugal is composed by a continental part and two archipelagos (Açores and Madeira). In addition, in relation to the percentage of people using smartphones to access the internet, the index in Brazil and Portugal is $67 \%$ - showing in these data a proximity to the adoption of this technology (CBwG, 2017). In addition to these considerations, which are not exhausted here but rather instigated, it is believed that the contacts of the researchers in the two countries constitute a favorable factor, in terms of access and interaction with sources of information.

This study is part of a wider research project aimed at characterizing and explaining the way governments decide on the adoption and use of mobile applications to interact with citizens. The paper is organized as follows: section two highlights the potential of m-government adoption in Brazil and Portugal; section three describes the methodology of the research; section four presents the results of the analysis of the 32 APPs; and section six outlines some final considerations.

\section{THE POTENTIAL OF M-GOVERNMENT IN BRAZIL AND PORTUGAL}

\subsection{Mobile and communication technology in Brazil and Portugal}

In order to highlight the potential of $\mathrm{m}$-Government as a further channel for service provision, this section presents figures that corroborate the adhesion of the Brazilian and Portuguese population to mobile technology. In Brazil, data from the National Household Sample Survey (PNAD-ICT Information and Communication Technologies), released in early 2018, showed that $64.7 \%$ of people - 10 years of age or older - used the Internet in 2016. The mobile phone was notably the most used equipment to access it $-94.6 \%$. The research also found that almost all $(99.7 \%)$ of the households with Internet had a broadband connection. Regarding the broadband type, the survey found that in $77.3 \%$ of the households there was mobile broadband ( $3 \mathrm{G}$ or $4 \mathrm{G}$ ), surpassing that of fixed broadband (71.4\%) [7]. Data from the National Telecommunications Agency (Anatel) show that in March 2018, Brazil recorded 235.78 million active lines in mobile telephony and a teledensity of 113.54 accesses per 100 inhabitants, which means that there is more than one mobile line for each Brazilian [8]. The Consumer Barometer with Google (CBwG), with data for 2017, indicates a percentage of $67 \%$ of people who use a smartphone to access the Internet [9].

In Portugal, according to the Digital Density Index - Portugal study "seven out of 10 mobile phone users have a smartphone" [10]. The Telecommunications Barometer, by the Marktest Group, in the mobile quarter of July 2018, accounted for approximately 6.9 million individuals with a smartphone, which means that for every four mobile phones, three are smartphones. This growing usage is evident when analyzing the period between 2012 and June 2018, where there was a growth of 46.2 percentage points in this type of device [13]. According to the Consumer Barometer with Google $(\mathrm{CBwG})$, the percentage of people in Portugal using smartphones to access the Internet is $67 \%$, equivalent to Brazil's [9].

\subsection{Mobile government applications in Brazil and Portugal}

As part of the strategy of the Brazilian government for the modernization and digitization of federal public services, a mapping process was carried out with the federal agencies of direct and indirect administration with the objective of identifying all the services offered to citizens. This research was carried out by ENAP (the National School of Public Administration) in partnership with the MPDG (Ministry of Planning, Development, and Management) and supports the service portal of the federal government (www.servicos.gov.br) [11]. This service portal provides a catalog of all government services as well as the delivery channels by which citizens can access each of them: faceto-face, web and mobile application. Based on the information available on this portal, it became clear that there were 32 services that had at least one step available through a "Mobile Application" channel was identified.

Just as in the case of Brazil, with a beta portal, at the time of this investigation, Portugal was also launching a portal bringing together mobile applications from Portugal - the site "App.Gov.pt" whose entity responsible for development and maintenance is the Agency for Administrative Modernization (AMA). The launch of this portal complies with a measure of the 2017 Simplex program, scheduled for the first quarter of 2018, which is called "APP Store Gov.PT". This measure is described as "creating a public web and mobile application (APP Store), aimed at citizens, adding and structuring all the mobile solutions of the State" [12].

With an approach different from that used in Brazil - based on a service relationship, Portugal offers a site with a list of public mobile applications and with the possibility to select them also by categories and operating systems (Android and iOS), in this site were listed 38 APPs. 
These were the initial numbers obtained in the official portals - 32 services related to mobile applications in Brazil and 38 APPs in Portugal. Considering the research criteria described in Study design, the study included in Brazil 12 APPs (which provide 25 services) and 20 APPs in Portugal (which provide 22 services).

\section{STUDY DESIGN}

The work conducted in this study was organized in three main phases, as described below.

Phase 1: Identify central government APPs in both countries.

The first step performed in this phase was to find out an institutional channel in each of the countries through which it would be possible to identify all the central government APPs available in the country. In Brazil, this channel was the www.servicos.gov.br portal, and in Portugal www.app.gov.pt, described in the previous section. Instead of doing that thorough ad-hoc google search, the use of an institutional channel to find the APPs ensured the identification of the complete set of central government APPs available in each country and not only a subset of them.

The second step was to search each of these two institutional channels in order to identify the existing APPs so that a concrete list of APPs for analysis in the study was produced. In this step, some APPs were discarded. In the case of Brazil, some applications - referenced in the official portal but not mobile applications and some services, provided through APP, that were not working were withdrawn from the study. In the case of Portugal, were withdrawn APPs that were not related to central administration, which were not available in APP stores, that the target public was not the citizen.

Table 1 shows the list of selected APPs and their respective services.

It is important to emphasize that the countries that are part of the study have different approaches regarding the way of offering services through APPs. Brazil provides a list of services offered to the citizen and the channels through which they can be accessed, among them are mobile applications. In Portugal, a portal lists the APPs available to perform certain services.

Table 1: APPs and services

\begin{tabular}{|c|c|}
\hline $\mathrm{APP}^{*}$ & SERVICES \\
\hline \multicolumn{2}{|r|}{ BRAZIL } \\
\hline Meu INSS & $\begin{array}{l}\text { Sign jail declaration. } \\
\text { Issue benefit payment statement. } \\
\text { Obtain PIS (Social Integration Program) or PASEP } \\
\text { (Public Server Patrimony Training Program) grant } \\
\text { letter and calculation memory. } \\
\text { Obtain declaration of non-receipt of INSS (National } \\
\text { Institute of Social Security) benefits. } \\
\text { Obtain declaration of regularity of individual } \\
\text { taxpayer's situation. } \\
\text { Obtain INSS income tax statement. } \\
\text { Obtain social security statement. } \\
\text { Get appropriation history. }\end{array}$ \\
\hline
\end{tabular}

\begin{tabular}{|c|c|}
\hline & $\begin{array}{l}\text { Get benefit review. } \\
\text { Receiving rural maternity wage. } \\
\text { Require early payment. } \\
\text { Request service at the National Institute of Social } \\
\text { Security. }\end{array}$ \\
\hline Pessoa Física & $\begin{array}{l}\text { Check situation of the restitution of the Income Tax. } \\
\text { Issue proof of cadastral status in the CPF (Physical } \\
\text { People Registry). } \\
\text { Subscribe to the Register of Individuals. }\end{array}$ \\
\hline Bolsa Família CAIXA & Get Family Grant Program's benefits. \\
\hline Caixa Trabalhador & Withdraw quotas of PIS or PASEP by age. \\
\hline Câmbio Legal & Make a purchase or sale of foreign currency. \\
\hline Consumidor.gov.br 1.2 & $\begin{array}{l}\text { Complain against service or product of private } \\
\text { companies. }\end{array}$ \\
\hline ENEM 2018 & Take the National High School Exam. \\
\hline FGTS & Take out the FGTS (Service Assurance Fund). \\
\hline IsF Aluno & Empower and certify in foreign languages. \\
\hline Salic & $\begin{array}{l}\text { Receive financial assistance for the participation of } \\
\text { cultural events and courses. }\end{array}$ \\
\hline Sisu & Subscribe to SISU (Unified Selection System). \\
\hline Turismo Acessível & Sign up for Affordable Tourism site. \\
\hline & PORTUGAL \\
\hline Algarve Events & Guide of events in the Algarve. \\
\hline $\begin{array}{l}\text { Cultural Itinerary of } \\
\text { Algarve }\end{array}$ & $\begin{array}{l}\text { Information about the main monuments, museums, } \\
\text { archeological sites of the Algarve region. }\end{array}$ \\
\hline INE Mobile & $\begin{array}{l}\text { Access to information and publications made } \\
\text { available by INE (National Institute of Statistics). }\end{array}$ \\
\hline NET.Mede & Measure the speed of the Internet connection. \\
\hline Rota Omíada no Algarve & Explore the Omíada tour in the Algarve region. \\
\hline Hidrográfico v2 & $\begin{array}{l}\text { Environmental information generated by Instituto } \\
\text { Hidrográfico - Marinha. }\end{array}$ \\
\hline MyADSE & $\begin{array}{l}\text { Information for its beneficiaries. } \\
\text { Online Digital Card. } \\
\text { Request European Health Insurance Card. }\end{array}$ \\
\hline MySNS Tempos & $\begin{array}{l}\text { Consult the average waiting time in the hospitals of } \\
\text { the National Health Service. }\end{array}$ \\
\hline Registo Viajante & $\begin{array}{l}\text { Information about each country of displacement } \\
\text { and contact facilitated with the user. }\end{array}$ \\
\hline SigaAPP & Withdraw service password public service. \\
\hline Comboios de Portugal & Check schedules and buy train tickets. \\
\hline MySNS & $\begin{array}{l}\text { Mobile link to the portal and digital health services } \\
\text { of the National Health Services. }\end{array}$ \\
\hline MySNS Transportes & $\begin{array}{l}\text { Consult the details of the transport of users of the } \\
\text { National Health Service. }\end{array}$ \\
\hline Autenticação Gov & $\begin{array}{l}\text { Alternative to sending the security code through } \\
\text { other channels and possibility to create new codes. }\end{array}$ \\
\hline Voa na Boa & $\begin{array}{l}\text { Information on the conditions under which the user } \\
\text { can fly with his Drone in the national territory } \\
\text { (Continental Portugal). }\end{array}$ \\
\hline IRS 2017 & $\begin{array}{l}\text { Deliver and consult IRS (Individual Income Tax) } \\
\text { statement } 2017 \text {. }\end{array}$ \\
\hline Mapa do Cidadão & Search of public services to the Citizen. \\
\hline Sit. Fiscal - Pagamentos & $\begin{array}{l}\text { Information about tax situation and possibility of } \\
\text { making payments. }\end{array}$ \\
\hline $\begin{array}{l}\text { Visit Portugal Travel } \\
\text { Guide }\end{array}$ & $\begin{array}{l}\text { Real-time tourist information and itinerary } \\
\text { organization. }\end{array}$ \\
\hline Meteo IPMA & $\begin{array}{l}\text { Weather and sea information for more than } 300 \\
\text { cities in the Portuguese territory. }\end{array}$ \\
\hline
\end{tabular}


Phase 2: Set the environment for the analysis.

In this phase, the basic conditions to initiate the analysis were set. This involved two main steps. First step was the definition of the set of criteria that would be used to conduct the analyses. The set of criteria are summarized in Table 2 .

Table 2: Criteria of analysis

\begin{tabular}{|c|c|}
\hline CRITERIA & DESCRIPTION \\
\hline Service Coverage & $\begin{array}{l}\text { (1) Partial: when only some steps of the service can be } \\
\text { performed through the APP, or when the application is the } \\
\text { gateway to the service, that is, it functions as a link to the } \\
\text { website where the service is available. } \\
\text { (2) Integral: when the service can be fully executed } \\
\text { through the APP. }\end{array}$ \\
\hline Service Category & $\begin{array}{l}\text { (1) Informational and Educational: service that are started } \\
\text { by the publisher. It involves the distribution of } \\
\text { information to citizens (general or specific). Examples } \\
\text { include: emergency alerts; health and safety education } \\
\text { (prevention and preparation); educational programs and } \\
\text { notifications. } \\
\text { (2) Interactive: service that allows the dialogue with } \\
\text { governments and sending of queries, problems, comments } \\
\text { or service requests to specific agencies. Access to forms, } \\
\text { applications, and databases is possible. Communication } \\
\text { becomes one-to-one rather than one-to-many. } \\
\text { (3) Transactional: bidirectional interaction between } \\
\text { citizens and government. Citizens can complete their } \\
\text { transactions with government electronically and at their } \\
\text { convenience. This includes self-service options for paying } \\
\text { taxes, payments, filing tax returns, soliciting services, and } \\
\text { other such interactions. } \\
\text { (4) Citizen Governance and Engagement: envisages citizen } \\
\text { involvement (to strengthen citizen-centred approach to } \\
\text { government and involve citizens in policy development } \\
\text { and decision-making), and elections and voting [4]. }\end{array}$ \\
\hline Service Area & $\begin{array}{l}\text { Refers to the government area in which service is } \\
\text { provided. }\end{array}$ \\
\hline $\begin{array}{l}\text { Number of } \\
\text { services provided } \\
\text { by the APP }\end{array}$ & Number of services provided by APP. \\
\hline $\begin{array}{l}\text { Number } \\
\text { Installations }\end{array}$ & $\begin{array}{l}\text { The number of times an APP has been downloaded. } \\
\text { This criterion is based on information available in the } \\
\text { Google Play store (Android). The APP Store (iOS) does not } \\
\text { provide this information. This means that the numbers } \\
\text { refer to users of smartphones with the Android operating } \\
\text { system. }\end{array}$ \\
\hline $\begin{array}{l}\text { Availability in } \\
\text { APP stores }\end{array}$ & $\begin{array}{l}\text { Used to verify that the APP was available for download on } \\
\text { Google Play and the Play Store. }\end{array}$ \\
\hline Access key & $\begin{array}{l}\text { It refers to the need or not of access key for APP to access } \\
\text { services provided on the APP and what the required access } \\
\text { keys are. }\end{array}$ \\
\hline
\end{tabular}

The second step was the download and installation of all the APPs on a smartphone.

Phase 3: APPs analysis.

In this phase, each of the 32 APPs identified in Phase 1 was analyzed takin into account the set of criteria defined in Phase 2 .

\section{STUDY FINDINGS}

This section presents the major findings from the analysis of the 12 APPs in Brazil and 20 APPs in Portugal offered by the central government of both countries. Table 3 summarizes the relevant figures.

Table 3: Summary of data

\begin{tabular}{|c|c|c|}
\hline CRITERIA & BRAZIL & PORTUGAL \\
\hline Total APPs & 12 & 20 \\
\hline $\begin{array}{l}\text { Number of } \\
\text { services }\end{array}$ & 25 & 22 \\
\hline $\begin{array}{l}\text { Number of } \\
\text { services } \\
\text { provided by } \\
\text { the APP }\end{array}$ & $\begin{array}{l}10 \text { APPs provide just one service } \\
2 \text { APPs provide more than one } \\
\text { service }\end{array}$ & $\begin{array}{l}19 \text { APPs provide just one service } \\
1 \text { APP provide more than one } \\
\text { service }\end{array}$ \\
\hline $\begin{array}{l}\text { Service } \\
\text { Coverage }^{*}\end{array}$ & $\begin{array}{l}\text { Integral: } 4 \text { APPs } \\
\text { Partial: } 9 \text { APPs }\end{array}$ & $\begin{array}{l}\text { Integral }=17 \text { APPs } \\
\text { Partial }=4 \text { APPs }\end{array}$ \\
\hline $\begin{array}{l}\text { Service } \\
\text { Category* }\end{array}$ & $\begin{array}{l}\text { Informative and } \\
\text { Educational: } 1 \mathrm{APP} \\
\text { Interactive: } 10 \mathrm{APPs} \\
\text { Transactional: } 2 \mathrm{APPs}\end{array}$ & $\begin{array}{l}\text { Informational and } \\
\text { Educational: } 8 \text { APPs } \\
\text { Interactive: } 9 \text { APPs } \\
\text { Transactional: } 3 \text { APPs }\end{array}$ \\
\hline $\begin{array}{l}\text { Service } \\
\text { Area }\end{array}$ & $\begin{array}{l}\text { Education and Research: } 3 \text { APPs } \\
\text { Work and Pension: } 3 \text { APPs } \\
\text { Finance, Tax and Public } \\
\text { Management: } 2 \text { APPs } \\
\text { Social Assistance: } 1 \text { APP } \\
\text { Culture, Arts, History and } \\
\text { Sports: } 1 \text { APP } \\
\text { Justice and Social Security: } 1 \\
\text { APP } \\
\text { Travel and Tourism: } 1 \text { APP }\end{array}$ & $\begin{array}{l}\text { Recreation: } 6 \text { APPs } \\
\text { Citizenship and } \\
\text { Documentation: } 5 \text { APPs } \\
\text { Social Support and Health: } 4 \\
\text { APPs } \\
\text { Money and Taxes: } 2 \text { APPs } \\
\text { Citizenship and Documen- } \\
\text { tation/Recreation: } 1 \text { APP } \\
\text { Immigration and Emigration/ } \\
\text { Recreation: } 1 \text { APP } \\
\text { Transport and Vehicles: } 1 \text { APP }\end{array}$ \\
\hline $\begin{array}{l}\text { Number of } \\
\text { installations }\end{array}$ & $\begin{array}{l}\text { Scattered between } 5.000 .000 \text { and } \\
1.000 \text { installations. }\end{array}$ & $\begin{array}{l}\text { Scattered between } 500.000 \text { and } \\
100 \text { installations. }\end{array}$ \\
\hline $\begin{array}{l}\text { Availability } \\
\text { in APP } \\
\text { stores }\end{array}$ & $\begin{array}{l}\text { Google Play }=12 \mathrm{APPs} \\
\text { APP Store }=10 \mathrm{APPs}\end{array}$ & $\begin{array}{l}\text { Google Play }=19 \text { APPs } \\
\text { APP Store }=18 \text { APPs }\end{array}$ \\
\hline Access key & $\begin{array}{l}\text { Not required }=1 \\
\text { Types of access key }=6\end{array}$ & $\begin{array}{l}\text { Not required }=10 \\
\text { Types of access key }=6\end{array}$ \\
\hline
\end{tabular}

A first finding of the analysis is concerned with the model adopted to offer services through APPs, in what refers the relationship between an application and the number of services it provides. As the numbers show, the 12 APPs analyzed in Brazil provided a total of 25 services to citizens, meaning that the relation between an APP and the number of services offered is not always a one-to-one relationship. A similar scenario was found in Portugal with 20 APPs providing 22 different services. Going deep in the analysis, we found that of the 12 APPs analyzed in Brazil 10 offered just one service to citizens (one-to-one relation) and two provided more than one service (one-to-many relation). These two cases were the APP "Meu INSS", which offered a total of 12 services, and "Pessoa Física", offering 3 services (see Table 1). In Portugal, out of the 20 APPs analyzed, 19 provided just one service and only one ("MyADSE") provided more than one service (3 services). This clearly shows a preference in both countries to adopt a "oneAPP-to-oneSevice" model rather than a "oneAPP-tomanyServices" model. 
In what concerns "Service Coverage", e.g. the number of steps of the service that can be performed through the APP (all steps integral; not all steps - partial), Brazil and Portugal performed in a different way. In Brazil, we found that most of the APPs (9 out of 12) do not provide an integral coverage of the services that they offer to citizens. This means that the APP can be used just to perform a sub-set of steps of the service. To fully complete the service, citizens need to use other channel of interaction with the government entity responsible for the service execution. In a particular APP (My INSS) some of the services are fully covered (10 out of the 12 services offered in this APP) and 2 are just partially covered. Contrarily, in Portugal 17 out of 20 APPs offer services that are fully covered by the APP; only in 4 APPs we found services partially covered. This is a criterion that may be influenced by the "Service category" criterion, since services in the "informative and educational services" category - which do not show great interaction between the agents - are possibly simpler to be carried out integrally by an APP.

In the criterion "Service Category", $77 \%$ of the Brazil's APPs provide services classified as "interactive service", with just $15 \%$ providing "transactional" services and 8\% "informative and educational services". The analysis in Portugal shows $45 \%$ of APPs offering services classified as "interactive service"; $40 \%$ providing "educational and information service" and $15 \%$ providing "transactional service". These figures reveal a similar predominance of categories in the countries, although with a meaningful difference of proportion among them (77\% of APPs offering "interactive service" against just $45 \%$ in Portugal). Additionally, it is worth to note that in neither of the countries we found APPs in the category "Citizen Governance and Engagement".

When looking at the "Service Area", it was clear that two areas share $50 \%$ of the applications in Brazil - Education and Research (25\%), Work and Pension (25\%); with $17 \%$ of the APPs falling in the area of Finance, Tax and Public Management. The remaining areas - Social Assistance; Culture, Arts, History and Sports; Justice and Social Security; Travel and Tourism - accounted for the remaining $33 \%$ of services provided through APPs. In Portugal, $75 \%$ of the APPs analyzed provide services on three areas: Recreation (30\%); Citizenship and Documentation (25\%); and Social Support and Health (20\%). Money and Taxes comes up with 10\%. The remaining areas - Citizenship and Documentation/ Recreation; Immigration and Emigration/Recreation; Transport and Vehicles - are offered only by $5 \%$ of the APPs.

The "number of installations" gives an interesting perspective about the potential acceptation, adoption and use of mobile applications by citizens, being a good indicator of the relevance of developing and making available services through mobile channels. For this reason, and despite the fact that these numbers pertaining only to the Android operating system, this criterion was considered in the analysis. In Brazil, the number of installations of each APP ranged between 5.000.000 and 1.000; in Portugal, between 500.000 and 100 installations (Table 4). These numbers are not reported for comparison reasons. A comparison at this level would not be possible at all, considering the contextual differences between countries, namely the size of population and so the number of potential users of the system.

Table 4: Number of installations

\begin{tabular}{|c|c|}
\hline $\mathrm{N}^{\circ}$ Installation & APPs \\
\hline \multicolumn{2}{|r|}{ BRAZIL } \\
\hline $5.000 .000+$ & Caixa Trabalhador, FGTS \\
\hline $1.000 .000+$ & Bolsa Família CAIXA; ENEM 2018; Pessoa Física; Sisu \\
\hline $100.000+$ & Meu INSS \\
\hline $50.000+$ & Câmbio Legal; Consumidor.gov.br \\
\hline $10.000+$ & IsF Aluno \\
\hline $5.000+$ & Turismo Acessível \\
\hline $1.000+$ & Salic \\
\hline \multicolumn{2}{|r|}{ PORTUGAL } \\
\hline $500.000+$ & Meteo IPMA \\
\hline $100.000+$ & Comboios de Portugal; MySNS \\
\hline $50.000+$ & $\begin{array}{l}\text { IRS 2017; Mapa do Cidadão; Sit. Fiscal - Pagamentos; Visit } \\
\text { Portugal Travel Guide }\end{array}$ \\
\hline $10.000+$ & $\begin{array}{l}\text { Hidrográfico v2; MyADSE; MySNS Tempos; Registo } \\
\text { Viajante; SigaAPP }\end{array}$ \\
\hline $5.000+$ & Autenticação Gov; Voa na Boa \\
\hline $1.000+$ & $\begin{array}{l}\text { Algarve Events; Cultural Itinerary of Algarve;INE Mobile; } \\
\text { NET.Mede;Rota Omíada no Algarve }\end{array}$ \\
\hline $100+$ & MySNS Transportes \\
\hline
\end{tabular}

The next criterion of analysis checked whether the APPs were made available for both Android and iOS platforms in the Google Play and APP Store stores, respectively, or just for one of them. The results show that, in the case of Brazil, all the 12 APPs were available in Google Play, but only 10 were available in APP store (the two applications missing in APPstore were Salic and Turismo Acessivel). In Portugal, of the 20 APPs analyzed, 19 were available in Google Play (just APP Registo Viajante was missing) and 18 were available in the APP Store (missing APPS were Hidrográfico v2 and MySNS Transportes). This means that most of the APPs in both countries are made available for both platforms (Android and iOS), providing this way universal availability of services through mobile devices, what is a key issue to ensure inclusion of citizens and equality of treatment by governments.

Regarding access keys, it was found that in Brazil $42 \%$ of the 12 APPs analyzed have as access key user's CPF and password; the CPF corresponds to a registration number in the "Cadastro de Pessoas Físicas" (Physical People Registry) maintained by the Brazil's federal revenue. NIS - "Número de Identificação Social" (Social Security Number - number that identifies Brazilian workers and citizens enrolled in social programs) and password are used by $17 \%$ of applications. Four other types of access keys are used by the rest of the applications. There is only one APP that does not require an access key (see Table 5).

In Portugal, $50 \%$ of the APPs do not require any type of access key; $20 \%$ use email and password; and 10\% use NIF (Tax Identification Number) and password. 
In some cases, when accessing for the first time to services that use as email/password as the access key, users are requested to perform a formal registration.

Table 5: Types of access key

\begin{tabular}{|c|c|}
\hline \multicolumn{2}{|c|}{ Access key } \\
\hline BRAZIL & PORTUGAL \\
\hline $\mathrm{CPF}$ and password $=5$ & No access key $=10$ \\
\hline NIS and password $=2$ & Email and password $=4$ \\
\hline $\mathrm{NIS}=1$ & NIF and password $=2$ \\
\hline $\mathrm{CPF}=1$ & Holder's number and password $=1$ \\
\hline ENEM registration and password $=1$ & Patient Number and mobile number $=1$ \\
\hline Email and password $=1$ & Phone number and PIN $=1$ \\
\hline No access key $=1$ & User and password $=1$ \\
\hline
\end{tabular}

\section{FINAL CONSIDERATIONS}

This study provides an overall perspective of the use of mobile applications to provide services to citizens by central administration institutions in Brazil and Portugal. It also allowed for the identification of a set of relevant and non-linear aspects that should be considered when designing APPs and when deciding about their use to provide public services.

The findings show that, given the number of services offered to citizens by the Central Administration of both countries, the use of mobile applications as an alternative channel to access services is still incipient.

The Brazilian portal "www.servicos.gov.br", in June 2018, provided around 760 public services, this study found only 25 services available through APPs. In Portugal, the "Portal do Cidadão" presents more than 1860 services (https://www.portaldo cidadao.pt/sobre-o-portal) and, as mentioned previously, only 22 services were identified as being available through APPs (in both cases, considering the criteria of this research - see section 3).

The study also shows that in Brazil the services offered through APPs are mainly "interactive services", that is services that allow bidirectional interaction with governments, such as pose queries, notify about problems, send comments or service requests to specific agencies. The same happens in Portugal. Only a very few number of the analyzed APPs in both countries provide "Transactional services" and, very interestingly and quite surprisingly, in neither of the countries we found APPs offering services classified in category "Citizen Governance and Engagement", that is services focused on strengthening promoting citizens engagement in policy development and decision-making, elections and voting. This points to the need to develop applications that support services with more advanced categories in terms of interaction with the citizen.

In what refers the relationship between an application and the number of services it provides, this study shown that two models can be adopted: a "oneAPP-to-oneSevice" model (one APP providing one services) and a "oneAPP-to-manyServices" model (the same APP providing multiple services). While both models were found in both countries, the model that clearly prevailed is the "oneAPP-to-oneService", being the one followed in $83 \%$ and
95\% of the APPs analyzed respectively in Brazil and Portugal. This seems to be a relevant and not linear aspect to consider when designing APPs. In fact, a one-to-many relationship may look the best option to create a certain thematic structuration of services offered through APPs, in the sense that it would allow, for instance, to group in the same APP many services of the same area (services in the social area, services in the financial area, etc.), or many services target to specific audiences (for the youth, for the elderly, etc.). However, there are also arguments that may justify the adoption of a "oneAPP-to-oneService" model.

The study also prompts out that many APPs just cover a partial set of steps involved in the execution of the service they offer. This constitutes undoubtedly another central point to reflect when designing and deciding about the adoption of APPs to provide a service to citizens. In fact, developing and making available an APP that covers only part of a service or, in the extreme case, that just provides a link to a website where the service is provided, as happens in some cases, may generate a big frustration in citizens, that after installing the application conclude that it ultimately does not help them to reach their goals.

Regarding the "Service Area" criterion, the study showed that in Brazil service delivery through mobile applications is growing more rapidly in the education, employment and environment sectors. Fifty percent of the Brazilian Apps analyzed in the study, are from the areas of Education and Research, Work, and Pension. This finding is in line with what is mentioned in the 2018 United Nations E-Government Survey [15], where it is stated that service delivery through mobile applications is growing more rapidly in the education, employment and environment sectors. Differently, in Portugal no such evidence was not found.

In relation to the "Number of installations", also considered in the study, it is important to stress again that the analysis conducted was just based on numbers for the Android operating system. A more realistic perspective would be obtained if we have these numbers also for iOS. It is also important to stress that the installation of an APP does not necessarily provides evidences about the actually usage of the APP. Therefore, despite this may be an important indicator for managers and developers, this numbers should be carefully analyzed and combined with complementary information.

Another aspect analyzed in this study was the availability of the APPs in the stores - Google Play and APP Store. At this level, the study clearly shown that in both countries there is a care to offer APPs versions for a service in both the stores. This is a core aspect to consider and to ensure, particularly when discussing the use of APPs to provide public services, which should be universally available to the citizens, independently of the type of smartphones used.

A final evidence that came up from analysis conducted for the 32 APPs was the need to have multiple access keys when interacting with the services provided through the different government APPs. This multiplicity of access keys is not convenient and may discourage the use of APPs. This seems, however, to be not a problem of service provision through APPs but a more general aspect of citizen interaction with government 
services, regardless of the channel through which services are provided.

This study provides an overall picture of mobile applications usage by central governments of Brazil and Portugal. Based on the analysis conducted, this paper also points out some central aspects that should be considered when designing or deciding about the use of APPs to provide public services. These aspects are not simple to address. Additional studies that help to understand how each of them can affect the successful design, provision, and use of APPs for public service provision are required, and should be part of the research agenda in the field of m-government.

\section{ACKNOWLEDGMENTS}

This work is a result of the project "SmartEGOV: Harnessing EGOV for Smart Governance (Foundations, methods, Tools) / NORTE-01-0145-FEDER-000037", supported by Norte Portugal Regional Operational Programme (NORTE 2020), under the PORTUGAL 2020 Partnership Agreement, through the European Regional Development Fund (EFDR).

\section{REFERENCES}

[1] Kushchu, I., \& Kuscu, H. (2003, July). From e-government to mgovernment: Facing the inevitable. Proceedings from The 3rd European Conference on e-Government (253-260). MCIL Trinity College Dublin, Ireland.

[2] Trimi, S., \& Sheng, H. (2008). Emerging trends in M-government. Communications of the ACM, 51(5), 53-58.

[3] Oui-Suk, U. (2010). "Introduction of m-Government \& IT Convergence Technology", working document, KAIST Institute for IT Convergence, Daejeon, Republic of Korea.

[4] Organisation for Economic Co-operation and Development - OECD (2011). M-governo: Mobile Technologies for Responsive Governments and Connected Societies. OECD Publishing. Available: https://www.itu.int/pub/D-STR-GOV.M_GOV-2011. Acessed on Set. 15, 2018

[5] United Nations - UN. 2016. American Society for Public Administration. Department of Economic and Social Affairs. E-Government Survey 2016 Available: https://publicadministration.un.org/egovkb/en-us/Reports/UNE-Government-Survey-2016. Acessed on Out. 10, 2018

[6] Ganapati S. (2015). Using mobile apps in government. The IBM Center for the Business of Government, Washington, D.C.

[7] IBGE. (2018). Pesquisa Nacional por Amostra de Domicílios Contínua. Acesso à Internet e à televisão e posse de telefone móvel celular para uso pessoal 2016. Available: https://agenciadenoticias.ibge.gov.br /media/com_mediaibge/arquivos/c62c9d551093e4b8e9d9810a6d3bafff.pdf. Acessed on Out. 13, 2018

[8] Agência Nacional de Telecomunicações - Anatel (2018). Telefonia Móvel. Available: http://www anatel gov br/dados/destaque-1/283-brasil-tem-2362-milhoes-de-linhas-moveis-em-janeiro-de-2018. Acessed on Out. 01, 2018

[9] Consumer Barometer with Google - CBwG. 2017. Available: https://www.consumerbarometer.com. Accessed on Out 24, 2017.

[10 Accenture. (2016). Índice de Densidade Digital - Portugal. Available:

] https://www.accenture.com/t00010101T000000 w /ptpt/_acnmedia/PDF-33/Accenture-Indice-de-Densidade-Digital-Portugalfinal.pdf. Acessed on Out. 04, 2018

[11 Filgueiras, F. \& Palotti, P. (2018).ENAP - Pesquisa Sobre Serviços Públicos de Atendimento do Governo Federal. Available: http://www.enap.gov.br Acessed on Out. 14, 2018

[12 Programa +Simplex 2017. (2017).República Portuguesa.

Available:https://www.simplex.gov.pt/app/files/

967ff098fcc6a0f72d2af69cfab39e70.pdf. Acessed on Out. 27, 2018

[13 Grupo Marktest. (2018). Barómetro de Telecomunicações.Penetração de

smartphone continua a aumentar. Available: https://www.marktest.com/ wap/a /n/id 23fd.aspx. Acessed on Out. 18, 2018.

[14 Gartner. (2018). Newsroom. Press Releases.

] Available: https://www.gartner.com/en/newsroom/press-releases/201802-22-gartner-says-worldwide-sales-of-smartphones-recorded-first-everdecline-during-the-fourth-quarter-of-2017 . Acessed on Out. 18, 2018

[15 United Nations - UN. 2018. Gearing e-Government to support

] transformation towards sustainable and resilient societies.. E-Government
Survey 2018. Available: https://publicadministration.un.org/egovkb/enus/Reports/UN-E-Government-Survey-2018. Acessed on Nov. 10, 2018 